Revista de

Contabilidade e

Organizações

www.rco.usp.br
DOI: http://dx.doi.org/10.11606/rco.v10i27.110553
Journal of

Accounting and

Organizations

www.rco.usp.br

\title{
A sistematização das normas contábeis no ordenamento jurídico brasileiro
}

\author{
Rogério Dias Correia ${ }^{a}$; Fábio Moraes da Costa ${ }^{a}$
}

${ }^{a}$ FUCAPE Business School

\section{Informações do Artigo}

Histórico do Artigo

Recebido: 12 de fevereiro de 2016

Aceito: 17 de agosto de 2016

Palavras chave:

Legalidade.

Eficiência.

Especificidade técnica.

Competência normativa.

Sistematização.

\begin{abstract}
Resumo
O presente estudo tem por objeto a normatização contábil no ordenamento jurídico brasileiro. Busca-se apresentar as espécies normativas contábeis, os critérios de solução de conflitos e, principalmente, delinear os contornos do exercício do poder normativo pelos órgãos e entidades pertencentes à administração pública em matéria contábil. Trata-se de uma sistematização da complexa teia normativa que versa sobre temas contábeis, composta por normas constitucionais, legais e infralegais. Através da análise do arcabouço normativo, conclui-se pela necessidade de uma releitura do princípio da legalidade, sob o enfoque do princípio da eficiência, para reconhecer um amplo campo de poder normativo aos órgãos e entidades pertencentes à administração pública, para estabelecer normas que tenham como objeto a evidenciação, mensuração e registro das operações, eventos e fatos econômicos.
\end{abstract}

Copyright (C) 2016 FEA-RP/USP. Todos os direitos reservados

\section{INTRODUÇÃO}

A adoção das International Financial Reporting Standards (IFRS) levou à aplicação de novos conceitos em Contabilidade, principalmente em países code-law, que internalizaram normas amplamente influenciadas pela filosofia common-law. Assim, a legislação passou a incorporar termos como valor justo e goodwill. Em função disso, o presente artigo tem como objetivo apresentar uma sistematização das normas contábeis frente ao ordenamento jurídico brasileiro, partindo da Constituição Federal e contemplando normas legais e infralegais.

A aplicação de novos conceitos e o dinamismo na alteração de normas contábeis gerou demanda para que a legislação brasileira fosse adaptada à nova realidade. Consequentemente, e em virtude do vasto e complexo conjunto de regramentos existente, torna-se necessária a avaliação, de maneira estruturada, sobre a hierarquização e a aplicabilidade de delegações realizadas no âmbito infralegal.

Os registros contábeis são utilizados há décadas para evidenciar a situação patrimonial das entidades em geral. Assim, a própria dinâmica negocial impôs a necessidade de uma padronização, mediante a juridicização de princípios e regras gerais norteadores dos registros contábeis, de modo a permitir que as informações pudessem ser, lógica e sistematicamente, interpretadas pelos seus usuários (stakeholders).

É da necessidade de padronização que se inicia o processo de normatização da contabilidade. O envolvimento dos diversos atores econômicos e as cada vez mais complexas e sofisticadas relações negociais, trouxe à tona a necessidade de fixação de normas gerais capazes de orientar não só os registros, mas também a geração de informações contábeis.

Nesse contexto, pretende-se proceder a uma sistematização da complexa teia normativa, envolvendo temas jurídico-contábeis; designadamente no que se refere ao exercício do poder regulamentar por parte dos entes reguladores que foram contemplados com poder de estabelecer normas contábeis para o setor não governamental. Busca-se, portanto, a apresentação de uma visão contemporânea do princípio da legalidade, interpretada à luz do princípio da eficiência, para que o ordenamento jurídico possa acompanhar a dinâmica negocial.

Autor Correspondente: Tel (27) 997242626

E-mail: roger.diasadv@gmail.com (R. D. Correia); fabio@fucape.br (F. M. Costa)

FUCAPE Business School - Av. Fernando Ferrari, 1358 - Boa Vista, Vitória - ES, 29075-505, Brasil. 


\section{O SISTEMA JURÍDICO CONTÁBIL BRASILEIRO}

\subsection{A normatização contábil em âmbito constitucional}

Apesar de não haver uma norma constitucional que verse diretamente sobre regramento contábil, é possível identificar alguns princípios gerais contidos na Constituição da República Federativa do Brasil (CRFB) que se relacionam mais de perto com a normatização contábil e que podem servir de norte para uma sistematização.

A CRFB/88 consagra a propriedade privada como um dos seus postulados basilares, ao definir, como regra, que a exploração direta da atividade econômica deve ser feita pela iniciativa privada. Trata-se de uma premissa fundamental que revela a opção pelo modelo capitalista de produção, lastreado na liberdade para empreender, em contraposição ao modelo de propriedade estatizada (FERNANDES, 2013, p. 37). Todavia, a propriedade privada não é um direito absoluto, pois deve atender a uma função social, no sentido de que, mesmo de forma mediata, o exercício individual da propriedade deve contribuir para o bem da coletividade.

Ao discorrer sobre o princípio da função social da empresa, Mamede (2011, p. 49) afirma que a livre iniciativa não pode ter por enfoque uma expressão egoísta, ou seja, "como trabalho de um ser humano em benefício de suas próprias metas, mas como iniciativa que, não obstante individual, cumpre um papel na sociedade".

O exercício da atividade econômica, de forma organizada para a produção ou a circulação de bens ou de serviços (art. 966 do Código Civil), pressupõe o reconhecimento da empresa como entidade apta a gerar riquezas que devem beneficiar não apenas os seus proprietários, mas, também, uma série de outros atores que, em conjunto, dão forma à noção de interesse público. Nesse cenário, a normatização contábil aparece como um instrumento de efetivação da função social da empresa, ao disciplinar a maneira como se deve proceder ao reconhecimento, à mensuração e à evidenciação das operações, eventos e fatos econômicos.

São os registros contábeis que permitem aos diversos usuários da contabilidade (stakeholders) tomar conhecimento da realidade empresarial, principalmente aqueles que não fazem parte do cotidiano da entidade. Do ponto de vista econômico, a divulgação de informações contábeis é um mecanismo amplamente utilizado de redução de assimetria informacional (HEALY e PALEPU, 2001).

Exemplos rotineiros da utilidade da contabilidade são o cálculo de participação nos lucros dos sócios e acionistas, uso em modelos de avaliação de empresas e de avaliação de capacidade para tomada de crédito (vide, por exemplo, AHMED et al., 2002). Ademais, a contabilização também instrumentaliza o poder público para fiscalizar o cumprimento das obrigações tributárias, pois registra os fatos econômicos que servem de supedâneo para as normas de incidência tributária (vide, por exemplo, o Decreto-Lei 1598, que disciplina o Imposto de Renda para Pessoas Jurídicas)

A parametrização normativa dos critérios que definem o processo de evidenciação alinha-se com o princípio da segurança jurídica, pois traz à tona critérios para instrumentalizar uma representação fidedigna, facilitando a fiscalização da atuação empresarial e a verificação quanto ao respeito (ou não) da sua função social.

Por outro lado, a CRFB/88 também lança as bases, mesmo que de forma sucinta, para uma separação patrimonial entre empresa e seus respectivos proprietários. Assim, estabelece que a lei, sem prejuízo da responsabilidade individual dos dirigentes da pessoa jurídica, estabelecerá a responsabilidade desta, sujeitando-se a punições compatíveis com sua natureza, nos atos praticados contra a ordem econômica e financeira e contra a economia popular (CRFB, art. 173, $\left.\S 5 .^{\circ}\right)$.

A distinção entre proprietários e empresa ganha corpo na legislação infraconstitucional, mediante a definição de limites à responsabilidade patrimonial dos sócios em alguns tipos societários, tal como nas empresas de responsabilidade limitada (LTDA) e nas Sociedades Anônimas. Cabe às normas contábeis a definição dos parâmetros que deve nortear essa segregação patrimonial e, ao mesmo tempo, evidenciar casos de confusão patrimonial, aptos a permitir a desconsideração da personalidade jurídica e a consequente responsabilização pessoal daqueles que não atenderam ao disposto na legislação (ver art. 50 do CC/2002).

Importa, ainda, fazer menção ao disposto no art. 170, IX, da CRFB/88 que estabelece como um dos princípios da atividade econômica o "tratamento favorecido para as empresas de pequeno porte constituídas sob as leis brasileiras e que tenham sua sede e administração no país". Trata-se de uma norma com repercussões relevantes para a normatização contábil, uma vez que dá uma diretriz a ser seguida no que tange à definição de parâmetros diferenciados para o reconhecimento, mensuração e registro dos eventos e fatos econômicos, tendo em vista as peculiaridades das empresas de menor porte. Assim, tal diferenciação acabou por resultar em pronunciamentos 
contábeis específicos, como a NBC TG 1.000 (CONSELHO FEDERAL DE CONTABILIDADE, 2009).

\subsection{A normatização contábil em âmbito legal}

Algumas leis esparsas fazem referência à Contabilidade. A título de exemplo, é possível citar as leis 8.666/93 (que institui normas para licitações e contratos da Administração Pública) e 11.101/2005 (que regula a recuperação judicial, a extrajudicial e a falência do empresário e da sociedade empresária). Todavia, tanto a lei n. ${ }^{\circ}$ 8.666/93 quanto a lei n. ${ }^{0}$ 11.101/2005 fazem menção a informações contábeis de forma genérica; a regulação mais detalhada ocorreu por meio de algumas disposições contidas nas leis 10.406/2002 (Código Civil Brasileiro) e 6.404/1976 (Lei das Sociedades por Ações).

A lei n. ${ }^{\circ}$ 10.406/2002 (Código Civil Brasileiro) trata, no título IV, capítulo III, de regras referentes à escrituração contábil, nos artigos 179 ao 1.195. Extrai-se de tais disposições uma série de normas cujo objetivo é delinear aspectos que envolvem o registro de informações contábeis. Dentre essas disposições, pode-se destacar algumas, como: a) a obrigatoriedade de se seguir um sistema de contabilidade, mecanizado ou não, com base na escrituração uniforme de seus livros, em correspondência com a documentação respectiva; b) obrigatoriedade de levantamento anual de balanço patrimonial e o de resultado econômico; c) a indispensabilidade do livro Diário: d) forma de escrituração no que toca ao idioma, moeda, cronologia e outros aspectos; e) critérios para avaliação do ativo.

A lei n. ${ }^{\circ} 10.406 / 2002$ ainda estabelece algumas normas que regulam a forma de exibição integral dos livros e papéis de escrituração, quando necessária, para resolver questões relativas à sucessão, comunhão ou sociedade, administração ou gestão à conta de outrem, ou em caso de falência (ver arts. 1.1190 ao 1.195).

Embora as normas contábeis previstas no Código Civil sejam genéricas, não adentrando em pormenores técnicos, elas têm sido alvo de críticas, principalmente pela utilização de terminologias inadequadas e algumas imprecisões conceituais que estariam na contramão do desenvolvimento da técnica contábil. Em razão disso, alguns autores chegam a afirmar que a regulação contábil prevista no Código Civil de 2002 contém algumas "atrocidades" do ponto de vista da técnica contábil, tratando-se de uma lei "totalmente extemporânea, fora da realidade nacional e com atrasos enormes", razão pela qual muitas de suas disposições não têm sido observadas pelos profissionais de contabilidade (MARTINS et. al., 2012, p. 14).

De fato, a regulação contábil prevista no Código Civil não se caracteriza por um rigor científico no que se refere à técnica contábil; assim, o intérprete não deve ater-se à mera literalidade dos seus dispositivos, mas se valer de todo o instrumental hermenêutico para extrair do texto legal o real sentido dos seus preceitos. Logo, a norma será o resultado do processo de atribuição de sentido ao enunciado que a ela dá suporte (STRECK, 2014, p. 316).

As impropriedades, atecnias e ambiguidades presentes nos textos legais são comuns, principalmente porque decorrem da manifestação de casas legislativas compostas por membros que, via de regra, não são técnicos com conhecimento específico na área regulada. Isso porque é próprio da democracia a existência de um poder legislativo com uma composição heterogênea, de modo que nele se façam representar os diversos segmentos da sociedade.

Nesse cenário, cabe ao intérprete valer-se de todo cabedal hermenêutico a sua disposição, com a finalidade de construir o conteúdo, o sentido e o alcance das normas jurídicas. Sobre o assunto, Carvalho (2005, p. 97) argumenta que há muitas situações em que será exigido do interprete uma intensa e profunda meditação, articulando-se regras dos mais variados setores da experiência jurídico-positiva, cruzando-os sob o pálio de princípios implícitos de difícil compreensão.

Entretanto, é preciso salientar que a atividade de interpretação tem limites e não pode servir para deturpar a opção política feita pelo legislador, titular de legitimidade democrática para impor normas primárias, tendo em vista o princípio da legalidade, corolário de um Estado Democrático de Direito. Logo, uma vez utilizado todo o cabedal hermenêutico e, mesmo assim, o resultado final não se mostre o mais "adequado" do ponto de vista da técnica contábil, a imposição legal não pode, simplesmente, ser descartada. Isso porque a norma jurídica goza de um atributo fundamental, que é a imperatividade, devendo ser cumprida mesmo que a desgosto de seus destinatários.

Kelsen (1998) argumenta que o Direito se distingue de outras ordens sociais, justamente pela possibilidade de se impor, ou seja, pelo poder de fazer valer suas proposições mesmo contra a vontade da pessoa atingida, ainda que para isso seja necessário o emprego da força. Com efeito, o inconformismo, muitas vezes legítimo, daqueles 
que lidam no seu cotidiano com disposições legais "inadequadas" não pode enveredar-se pela trilha da ilegalidade; o caminho a seguir deve ser o de empreender diligências para sensibilizar o legislador quanto à necessidade de promover as alterações pertinentes, respeitando-se o procedimento constitucionalmente estabelecido. Desse modo, preserva-se a segurança jurídica, valor estruturante de um Estado Democrático de Direito.

A lei n. ${ }^{\circ} 6.404 / 76$, alterada por algumas leis posteriores, também traz um capítulo específico sobre aspectos contábeis aplicáveis às Sociedades Anônimas por Ações, e, diferentemente da lei n. ${ }^{0}$ 10.406/2002, traz à baila uma regulamentação mais densa, impondo uma série de normas primárias que devem ser observadas pelos seus destinatários. Essa lei versa sobre diversos temas, dentre os quais se destacam: a) indicação das demonstrações financeiras e os critérios para sua elaboração; b) definição do regime de competência; e c) critérios de avaliação de ativos e passivos.

Nesse cenário, o marco legal que regula o reconhecimento, a mensuração e o registro dos fatos econômicos passa pelas disposições das leis 10.406/2002 e 6.404/76, uma vez que elas introduzem, no ordenamento jurídico brasileiro, normas primárias com aptidão para inovar e impor comportamentos a seus destinatários. Todavia, é preciso apontar que existe uma necessidade de demarcar o âmbito de incidência da lei n. ${ }^{\circ} 10.406 / 2002$ e da lei n. ${ }^{\circ}$ 6.404/1976, visto que ambas tratam de questões contábeis, às vezes, de forma incompatível. Para tanto, costuma-se apontar três critérios normativos para a resolução de conflitos, sendo eles: o critério hierárquico, o cronológico e o da especialidade (BOBBIO, 1999).

Pelo critério hierárquico, havendo um conflito de normas que pertencem a níveis diferentes, deve prevalecer a lei superior. Pelo critério cronológico, quando duas normas do mesmo nível ou escalão entram em rota de colisão, deve prevalecer a lei posterior, ou seja, aquela que foi editada por último. Já pelo critério da especialidade, a lei especial deve prevalecer sobre lei geral quando conflitarem entre si, sendo que lei específica é aquela que colhe algumas peculiaridades de natureza objetiva ou subjetiva, para conferir um tratamento diferenciado, manifestando seu caráter excepcional em relação à regra geral.

Tanto a lei n. ${ }^{\circ} 10.406 / 2002$ quanto a lei n. ${ }^{\circ}$ 6.404/1976 são leis ordinárias que gozam do mesmo status hierárquico no sistema normativo. Com efeito, o critério hierárquico não serve ao propósito de solucionar potenciais antinomias, pois nenhuma das normas serve de fundamento de validade para a outra.

Pelo critério cronológico, tendo sido a lei n. ${ }^{0} 10.406 / 2002$ editada posteriormente à lei n. ${ }^{\circ} 6.404 / 76$, aquela deveria prevalecer, uma vez que refletiria a manifestação normativa mais recente do legislador. Sendo assim, no caso de incompatibilidade, dever-se-ia entender que a lei n. ${ }^{\circ}$ 10.406/2002 teria revogado implicitamente as disposições contidas na lei n. ${ }^{\circ}$ 6.404/1976. Contudo, uma análise mais detida da situação posta revela a possibilidade de manter-se a vigência das duas normas em comento, mesmo que incompatíveis, tomando a especialidade como critério normativo para a resolução de conflitos.

As prescrições contidas nos arts. 1.179 ao 1.195 da lei n. ${ }^{\circ} 10.406 / 2002$ estabelecem normas gerais sobre escrituração contábil para os diversos tipos societários (ou de empresa) previstos no nosso ordenamento jurídico. Logo, trata-se de regras comuns que devem ser observadas, de forma geral, pelas diversas espécies societárias previstas no próprio Código Civil, tais como as sociedades simples, as sociedades em nome coletivo, as sociedades em comandita simples e as sociedades limitadas.

Já a lei n. ${ }^{\circ}$ 6.404/1976 foi editada com a finalidade de estabelecer normas voltadas especificamente para as Sociedade Anônimas por Ações, um tipo societário dotado de maior complexidade, a ponto de merecer um tratamento singular por parte do legislador, inclusive no que se refere às regras atinentes à escrituração contábil.

Desse modo, com base no critério da especialidade, tanto a lei n. ${ }^{\circ}$ 10.406/2002 quanto a lei n. ${ }^{\circ}$ 6.404/1976 podem conviver harmonicamente. A primeira regula as empresas e sociedades empresariais que não sejam constituídas sob a forma de Sociedade Anônima por Ações e as Sociedades em Comandita por Ações naquilo em que houver tratamento específico (ver art. 1.190 do CC/2002). Isso porque, para essas duas últimas espécies societárias, o legislador definiu um tratamento legislativo diferenciado, em consonância com as peculiaridades que a elas são inerentes.

Importa ressaltar que as Sociedades Anônimas por Ações e as Sociedades em Comanditas por Ações também deverão observar as normas contidas na lei $\mathrm{n}^{\circ}$ 10.406/2002 naqueles aspectos gerais que não mereceram um tratamento específico na lei n. ${ }^{\circ} 6.404 / 1976$. É o caso, por exemplo, das regras contidas nos art. 1.185 a 1.190, que tratam de normas referentes à apresentação dos documentos contábeis. Nesses termos, é preciso reconhecer que o próprio sistema jurídico traz uma solução para o problema, havendo, portanto, uma antinomia meramente aparente. Essa conclusão é reforçada pelo disposto no art. 1.089 da lei 10.404/2002, ao prescrever que: "a sociedade anônima rege-se por lei especial, aplicando-se-lhe, nos casos omissos, as disposições deste Código." 
É fato que há os que defendam a aplicação pura e simples da lei n. ${ }^{\circ} 6.404 / 1976$ a todos os casos, por considerá-la tecnicamente superior. Contudo, valem aqui as observações que fizemos anteriormente no sentido de que, tendo o legislador feito uma opção política juridicamente válida, ela deve ser acatada, mesmo que haja discordância quanto ao tratamento legal dado à matéria.

\subsection{A normatização contábil em âmbito infralegal}

Além das normas contábeis introduzidas non sistema jurídico pelas leis 10.406/2002 e 6.404/1976, existe, ainda, no sistema jurídico brasileiro, uma vasta gama de normas contábeis que tem como suporte atos normativos infralegais. São preceitos normativos expedidos com base no poder normativo atribuído, via delegação legislativa, a órgãos e entes integrantes da administração pública. Tais preceitos são chamadas de atos normativos infralegais pelo fato de estarem localizadas hierarquicamente abaixo das leis, pois decorrem da manifestação do poder executivo, sem a participação do poder legislativo que, nos termos da teoria da separação dos poderes, é o legitimo titular da função de criar leis.

Com efeito, é importante tecer algumas considerações sobre o poder normativo no sistema jurídico brasileiro para, a partir daí, demarcar a extensão e os limites que a ele são inerentes, sobretudo no que se refere à área contábil.

\subsubsection{O poder regulamentar}

De acordo com Mello (2011, p. 343), o poder regulamentar é a competência privativa, atribuída ao chefe do poder executivo, para produzir disposições operacionais uniformizadoras, necessárias à execução de lei cuja aplicação demande atuação particular por parte da Administração Pública. Com efeito, o exercício do poder regulamentar serviria apenas para desdobrar o conteúdo sintético da lei, para explicar didaticamente seus termos, de modo a facilitar a sua execução, não podendo acrescentar ou restringir as disposições legais, sob pena de afronta ao princípio da legalidade.

Ocorre que a adoção irrestrita da tese de Mello (2011) implicaria reconhecer a inconstitucionalidade de quase todo o sistema regulatório brasileiro, principalmente na seara econômica, visto que ele se concretiza mediante uma atuação pujante de órgãos e entes administrativos dotados de amplos poderes regulatórios. Entretanto, essa não aparenta ser a solução eficiente, pois há espaço para uma interpretação adequada à atual conjuntura, marcada por um mundo globalizado e dinâmico. Assim, Sampaio (2011, p. 214) alega ser necessária uma releitura do princípio da legalidade à luz do princípio da eficiência, introduzido no art. 37 da CRFB/88, através da Emenda Constitucional n. ${ }^{\circ}$ 19/1998.

Sampaio (2011) propõe que a legalidade seja vista em termos de uma legitimação finalística dos atos administrativos, de maneira que os atos sejam legítimos quando consigam atingir os objetivos estabelecidos em lei de formal proporcional. Assim, o princípio da eficiência exige que se atribuam competências reguladoras de natureza técnica e especializada à Administração Pública, sob pena de paralisia, pois seria impossível exigirse eficiência da Administração Pública sem dar a ela poder para alocar fins específicos e encontrar os meios adequados ao cumprimento desses mesmos fins (SAMPAIO, 2011).

Em sentido semelhante, Grau (2000, p. 172) afirma que é necessário compreender que o processo de desenvolvimento implica uma dinâmica mobilidade social correspondente a adoção de uma nova visão da realidade num sentido prospectivo. Assim, devem ser afastadas concepções que vislumbram, na norma jurídica, uma regra primordial e fundamente estaticamente considerada. O Direito necessita estar em constante mutação, impondo-se à superação do descompasso existente entre o ritmo de evolução das realidades sociais e a velocidade de transformação da ordem jurídica.

É fato que o cenário econômico está sujeito a permanentes flutuações, de maneira que mudanças conjunturais podem ocorrer rapidamente. Numa perspectiva contemporânea, é preciso reconhecer a necessidade de uma flexibilização dos mecanismos tradicionais de alteração normativa, de modo que o Estado tenha condições para corrigir, em tempo, os desvios ocorridos no desenrolar do processo econômico e no curso das políticas públicas que esteja a implementar.

Todavia, defender a possibilidade de normatização por meio de preceitos normativos infralegais não 
significa, de modo algum, outorgar um cheque em branco a órgãos ou entes administrativos de natureza técnica para, livremente, impor comportamentos. Também não implica admitir uma subversão na clássica hierarquização das fontes normativas, equiparando fontes normativas secundárias às fontes normativas primárias. Isso porque o poder regulamentar, mesmo interpretado à luz do princípio da eficiência, encontra-se sujeito a balizas. Qualquer violação a essas balizas torna abusiva a normatização e viola a ordem jurídica, demandando uma reação com vistas a reestabelecer a harmonia sistêmica.

Por essa razão, é necessário identificar algumas diretrizes que podem servir de parâmetros para o exercício do poder normativo por parte dos órgãos e entes administrativos. Trata-se de uma tarefa bastante difícil, pois implica reconsiderar muitas concepções tradicionais que, entranhadas em nossa cultura jurídica, foram alçadas, por muitos, à condição de verdadeiros dogmas jurídicos. Para tanto, é necessário considerar o princípio da legalidade numa perspectiva de maior dinamismo, considerando-o em imanente conexão com o princípio da eficiência que, desde a Emenda Constitucional n. ${ }^{\circ}$ 19/1998, passou a ser um dos pilares da atuação da Administração Pública. A seguir, são apresentadas algumas diretrizes que podem ser úteis na implementação desta tese:

Primeiro. As normas editadas no exercício do poder regulamentar devem ser compatíveis com os standards contidos na lei. Logo, não cabe à normas regulamentares ab-rogar, modificar, suspender e nem mesmo atenuar preceitos legais que a elas servem de fundamento, uma vez que o nosso ordenamento jurídico não admite regulamentação contrária à lei. Isso não significa, entretanto, que as normas regulamentares devem limitar-se à mera execução dos preceitos legais; elas podem, sim, inovar, desde que o façam de forma compatível com os fins visados pelo legislador, designadamente através da imposição de comportamentos que sejam necessários para dar efetividade aos comandos legais (MOREIRA, 2011, p. 142).

Segundo. Os agentes públicos, responsáveis pela emanação normativa, devem ser técnicos e não políticos, pois a conversão da função administrativa em função política descarta o verdadeiro escopo legal e pode dissimular um desvio de finalidade (FILHO, 2011, p. 68). Ademais, esse tipo de produção normativa deve resultar de uma ampla discussão com especialistas no setor a ser regulado, de modo a buscar um certo grau de convergência técnica e, por outro lado, atenuar o déficit democrático desse tipo de manifestação normativa.

Terceiro. Os comandos decorrentes do exercício do poder normativo que não se limitem a promover a fiel execução da lei, mas inovem criando diretos e obrigações (desde que expressa e previamente autorizados em lei) devem ser medidos pelo princípio da proporcionalidade, em termos de necessidade e adequação, tendo-se como parâmetros os fins visados pela lei autorizadora, além, é claro, de estarem em conformidade com os valores constitucionalmente reconhecidos.

Tratam-se apenas de alguns vetores que podem ajudar a controlar a produção normativa que seria exógena e que traria riscos ao princípio da legalidade. É uma maneira de não gerar paralisia em setores econômicos mais dinâmicos, permitindo a existência de mecanismos mais ágeis de normatização e, ao mesmo tempo, prestigiar valores que são caros num Estado Democrático de Direito que tem, na lei formal, um dos seus pilares de sustentação.

Logo, é preciso empreender uma releitura do princípio da legalidade em estreita conexão com o princípio de eficiência, de modo a contemporizar as mudanças que os novos tempos impõem ao convívio social.

\section{3 ÓRGÃOS E ENTIDADES COM COMPETÊNCIA NORMATIVA EM MATÉRIA CONTÁBIL}

Dentro do escopo de dar celeridade à normatização contábil, algumas leis delegaram a órgãos e entidades da Administração Pública competência para estabelecer normas contábeis.

O primeiro diploma legal a delegar poder normativo em matéria contábil foi a lei $n .^{\circ} 4.595$, de 29 de dezembro de 1964. Essa lei delegou competência ao Conselho Monetário Nacional (CMN) para expedir normas gerais de contabilidade e estatística a serem observadas pelas instituições financeiras (art. $4 .^{\circ}$, XII). Trata-se de um diploma com aplicação restrita, uma vez que se refere apenas a instituições financeiras, não se aplicando, portanto, a outras entidades pertencentes a outros setores.

Posteriormente, a lei n. ${ }^{\circ} 4.728$, de 14 de julho de 1965, com a finalidade de disciplinar o mercado de capitais, reafirmou a delegação de poderes ao CMN para expedir normas a serem observadas pelas pessoas jurídicas de direito privado registradas no Banco Central relativas a: a) natureza, detalhe e periodicidade da publicação de informações sobre a situação econômica e financeira da pessoa jurídica; b) organização do balanço e das demonstrações de resultado, padrões de organização contábil, relatórios e pareceres de auditores independentes 
registrados no Banco Central (art. 20, § 1. ${ }^{\circ}$, alíneas “a" e "b")

Em 21 de novembro de 1966 foi editado o decreto-lei n. ${ }^{\text {o } 73 . ~ E s s e ~ d i p l o m a ~ n o r m a t i v o ~ c r i o u ~ o ~ C o n s e l h o ~}$ Nacional de Seguros privados (CNSP), conferindo a esse órgão competência para, dentre outras coisas, fixar normas gerais de contabilidade e estatística a serem observadas pelas Sociedades Seguradoras (art. 32, V).

Mais uma delegação normativa adveio por meio da lei n. ${ }^{\circ}$ 6.385/1976, que atribui à Comissão de Valores Mobiliários (CVM) poder para expedir normas aplicáveis às companhias abertas sobre: a) natureza das informações que devam divulgar e a periodicidade da divulgação; b) relatório da administração e demonstrações financeiras; c) padrões de contabilidade, relatórios e pareceres de auditores independente (art. 22, § 1..$^{\circ}$ ). O $\S 3 .^{\circ}$ do art. 177 da lei 6.404/1976 (com redação dada pela lei 11.941/2009) reafirma a competência normativa da CVM, ao preceituar que as demonstrações financeiras das companhias abertas devem observar as normas por ela expedidas.

Por fim, o art. 76 da lei n. ${ }^{\circ}$ 12.249/2010 acrescentou a alínea “j” ao artigo 6. ${ }^{\circ}$ do decreto-lei n. ${ }^{\circ}$ 9.295/1946, atribuindo ao Conselho Federal de Contabilidade (CFC) a competência para regular acerca dos princípios contábeis, exame de suficiência, cadastro de qualificação técnica e programas de educação continuada e editar Normas Brasileiras de Contabilidade de natureza técnica e profissional.

Tais órgãos e entidades gozam de um elevado grau de autonomia e capacidade normativa; exercem um papel relevante no cenário econômico, designadamente no que se refere ao estabelecimento de normas de natureza técnica, necessárias para o bom funcionamento do mercado. Cabe a tais órgãos e entidades, respeitados os standards, contidos nas leis que regulam os temas que a eles foram afetos, estabelecer regulamentações contábeis, promovendo seu detalhamento e maneira de aplicação.

Nesse papel, o CMN, o CNSP, a CVM e o CFC não estão circunscritos ao estabelecimento de decretos executivos com a finalidade de promover a fiel execução da lei, pois podem, sim, inovar em matérias técnicas, criando direitos e obrigações, desde que o façam em estrita consonância com as normas primárias que versam sobre o tema a ser regulado e passem pelo filtro do princípio da proporcionalidade.

Vale destacar que a existência de quatro centros com aptidão para estabelecer normas em matéria contábil poderia conduzir a um cenário de confusão normativa, decorrente da dificuldade de se identificar qual norma deve ou não ser aplicada em caso de tratamento normativo diverso. Todavia, tal conflito pode ser resolvido pelas próprias regras impostas pelo sistema jurídico, havendo um conflito, em termos de competência normativa, apenas aparente, pois as próprias leis que delegam competência normativa ao CMN, ao CNSP, à CVM e ao CFC estabelecem quais são os sujeitos que devem observar os preceitos normativos editados por cada um deles. Logo, o critério para identificar a norma aplicável há de ser o da especialidade.

Em síntese, pode-se afirmar que:

a) as instituições obrigadas ao registro no Banco Central Brasileiro (BACEN) ficam vinculadas às normas expedidas pelo CMN, seja qual for o regime societário que adotem;

b) as sociedades seguradoras ficam vinculadas às normas contábeis expedidas pelo CNSP, consoante prescreve o art. 32, V, do decreto-lei n. ${ }^{\circ}$ 73/1966, independentemente da forma societária;

c) as sociedades constituídas sob a forma de Sociedade Anônima com capital aberto (art. 177, § 3. , da lei 6.404/1976) ficam vinculadas às normas expedidas pela CVM, ressalvadas aquelas que se dediquem a atividades financeiras e à exploração de seguros privados, as quais estarão sujeitas à regulação do CMN e do CNSP, respectivamente;

d) as demais entidades que não se enquadrem nas situações acima referidas estarão vinculadas às normas expedidas pelo CFC, que, nesses termos, dispõe de um poder normativo residual, na medida em que poderá estabelecer normas de contabilidade para as demais entidades que não estejam vinculadas às normas expedidas pelo CMN, CNSP e CVM.

Por fim, ainda importa referir à situação das Sociedades Anônimas de capital fechado e das Sociedades de Grande Porte, tendo em vista o tratamento peculiar que a elas foi dado pela legislação. O $\S 6 .^{\circ}$ do art. 177 da lei n. ${ }^{\circ} 6.404 / 1976$ preceitua que as companhias fechadas poderão optar por observar as normas sobre demonstrações financeiras expedidas pela CVM para as companhias abertas.

Vislumbra-se, aqui, uma faculdade concedida às Sociedades Anônimas de capital fechado, as quais poderão seguir ou não as normas expedidas pela CVM. Caso não façam essa opção, tais entidades deverão obedecer às normas expedidas pelo CFC, tendo em vista a competência normativa residual conferida a essa entidade. Ressaltese, contudo, que essa opção se refere apenas às Sociedades Anônimas de capital fechado que não explorem atividade financeira ou de seguros, visto que estas estão vinculadas ao CMN e ao CNSP, respectivamente. 
Já no que toca às Sociedades de Grande Porte, o art. 3. ${ }^{\circ}$ da lei 11.638/2007 preconiza que:

\begin{abstract}
Aplicam-se às sociedades de grande porte, ainda que não constituídas sob a forma de sociedades por ações, as disposições da Lei ${ }^{\circ}$ 6.404, de 15 de dezembro de 1976, sobre escrituração e elaboração de demonstrações financeiras e a obrigatoriedade de auditoria independente por auditor registrado na Comissão de Valores Mobiliários.

Parágrafo único. Considera-se de grande porte, para os fins exclusivos desta Lei, a sociedade ou conjunto de sociedades sob controle comum que tiver, no exercício social anterior, ativo total superior a R $\$ 240.000 .000,00$ (duzentos e quarenta milhões de reais) ou receita bruta anual superior a $\mathrm{R} \$ 300.000 .000,00$ (trezentos milhões de reais).
\end{abstract}

Percebe-se, no preceito supracitado, uma imposição para as Sociedades de Grande Porte, no sentido de observar as normas sobre escrituração e elaboração de demonstrações financeiras, de acordo as disposições da lei n. ${ }^{\circ}$ 6.404/1976, que trata sobre as Sociedades Anônimas. Ocorre que a própria lei n. ${ }^{\circ}$ 6.404/1976 faz uma distinção entre as Sociedades Anônimas de capital aberto e Sociedades Anônimas de capital fechado. As primeiras devem, necessariamente, seguir as normas expedidas pelas CVM (art. 177, $\S 3 .^{\circ}$ ) enquanto que as segundas podem optar por segui-las ou não (art. 177, § 6. ${ }^{\circ}$ ).

Desse modo, a questão fulcral é saber se as Sociedades de Grande Porte estão obrigadas a seguir as normas infralegais expedidas pela CVM, como ocorre com as Sociedades Anônimas de capital aberto, ou se, ao revés, gozam da faculdade de segui-las ou não, a exemplo do que ocorre com as Sociedades Anônimas de capital fechado. Trata-se de uma questão complexa, na medida em que a simples literalidade do art. $3 .^{\circ}$ da lei $\mathrm{n}^{\circ}$ 11.638/2007 não fornece um critério explícito de solução.

Todavia, a melhor interpretação é aquela que equipara a empresa de grande porte às Sociedades Anônimas de capital fechado, no sentido de que a observância das normas expedidas pela CVM será facultativa, podendo tais entidades optar por seguir as normas expedidas pelo CFC, caso não estejam subordinadas ao poder normativo do CMN ou do CNSP.

Confirma esse entendimento o fato de o art. $3 .^{\circ}$ da lei n. ${ }^{\circ} 11.638 / 2007$ falar apenas em escrituração e elaboração de demonstrações financeiras e não fazer qualquer referência ao dever de publicação, tal como ocorre com as Sociedades Anônimas de capital fechado.

Logo, embora estejam obrigadas às disposições contábeis previstas na lei n. ${ }^{\circ}$ 6.404/1976, as sociedades de grande porte não estão obrigadas a seguir as normas expedidas pela CVM. Com efeito, podem optar por seguir as normas expedidas pelo CFC, caso não se dediquem à exploração de atividades financeiras e de seguro, visto que estas últimas estão sujeitas às normas expedidas pelo CMN e pelo CNSP, respectivamente.

\title{
4 O PROCESSO DE CONVERGENCIA ÀS NORMAS INTERNACIONAIS DE CONTABILIDADE (IFRS)
}

No ano de 1973, mediante a conjunção de esforços de alguns organismos profissionais de contabilidade de alguns países foi criado um Comitê Internacional de pronunciamentos contábeis denominado International Accounting Standards Committee (IASC). Era uma entidade privada independente, sem fins lucrativos, que tinha por objetivo estabelecer uma padronização de normas contábeis, aproximando as regras existentes nesses diversos países, de modo a facilitar o fluxo de informações.

Com vistas a melhorar a estrutura técnica de formulação e validação dos novos pronunciamentos contábeis internacionais, foi criado, no ano 2001, o International Accounting Standards Boards (IASB). Essa entidade assumiu as responsabilidades técnicas do IASC, e, a partir de então, passou a emitir os denominados IFRS (International Financial Reporting Standards).

Diante da necessidade de convergência aos padrões de contabilidade internacional, foi criado, no Brasil, por meio da Resolução CFC n ${ }^{\circ}$ 1.055, de 07 de outubro de 2005, o Comitê de Pronunciamentos Contábeis (CPC), com o objetivo de estudar, preparar e emitir Pronunciamentos Técnicos sobre procedimentos de Contabilidade e a divulgação de informações dessa natureza, visando à centralização e uniformização do seu processo de produção $\left(\right.$ art. $\left.3 .^{\circ}\right)$ 
O CPC decorreu da conjunção de esforços e comunhão de objetivos das seguintes entidades: a) ABRASCA - Associação Brasileira das Companhias Abertas; b) APIMEC NACIONAL - Associação dos Analistas e Profissionais de investimento do mercado de capitais; c) BOVESPA - Bolsa de Valores Mercadorias e Futuros; d) CFC - Conselho Federal de Contabilidade; e) FIPECAFI - Fundação Instituto de Pesquisas Contábeis, Atuariais e Financeiras; f) IBRACON - Instituto dos auditores Independentes. Outras entidades também são convidadas a participar das discussões, democratizando-se, assim, os debates de natureza técnica.

O $\S$ único do art. 2. ${ }^{\circ}$ da Resolução CFC n. ${ }^{\circ}$ 1.055/2005 estabelece a possibilidade de admissão de novos membros ao CPC. Segundo esse dispositivo, outras entidades ou instituições vinculadas a contadores, auditores, analistas de investimentos ou de Demonstrações Contábeis, relacionadas ao mercado financeiro, em geral, ou ao mercado de capitais, em particular, bem como representantes de universidades que possuam cursos de Contabilidade, reconhecidos como de alta qualidade ou institutos de pesquisas na área contábil vinculados a universidades que mantenham tais cursos, poderão vir a ser convidadas a integrar o Comitê de Pronunciamentos Contábeis (CPC).

A aceitação de novos membros fica condicionada à aprovação de $3 / 4$ (três quartos) das entidades originariamente representadas no CPC, havendo, ainda, a possibilidade de exclusão de membros, pelo mesmo quórum de aceitação, observada a manutenção de equilíbrio entre os setores nele representados.

O CPC atua mediante uma estrutura física, biblioteca, recursos humanos e tecnológicos, fornecidos pelo CFC. Contudo, trata-se de um órgão totalmente autônomo, não existindo qualquer relação de hierarquia ou mesmo de subordinação com as entidades que dele fazem parte.

Além dos representantes que tem assento permanente no CPC, serão sempre convidados a participar das reuniões os seguintes órgãos: a) Comissão de Valores Mobiliários - CVM; b) Banco Central do Brasil - BACEN; c) Superintendência dos Seguros Privados - SUSEP; d) Secretaria da Receita Federal do Brasil - SRFB; e) Federação Brasileira de Bancos - FEBRABAN; e) Confederação Nacional da Indústria - CNI.

O CPC poderá convidar para suas reuniões, a critério do seu Coordenador Técnico ou por deliberação de 1/3 (um terço) dos seus membros, especialistas e representantes das agências reguladoras e de entidades que possam colaborar com temas específicos. Contudo, tais entidades podem apenas opinar, não tendo direito à voto (art. 11 do regimento do $\mathrm{CPC}$ )

Segundo o art. $4 .^{\circ}$ da Resolução do CFC n. ${ }^{\circ} 1.055 / 2005$, é atribuição do Comitê de Pronunciamentos Contábeis (CPC) estudar, pesquisar, discutir, elaborar e deliberar sobre o conteúdo e a redação de pronunciamentos técnicos. Poderá, ainda, emitir orientações e interpretações, além dos pronunciamentos técnicos, sendo que todos poderão ser consubstanciados em Norma Brasileira de Contabilidade pelo CFC ou em atos normativos emitidos pelos demais agentes reguladores, visando dirimir dúvidas quanto à implementação desses pronunciamentos técnicos (art. $\left.4 .^{\circ}, \S 1 .^{\circ}\right)$.

As minutas dos pronunciamentos técnicos serão obrigatoriamente submetidas a audiências públicas (art. $6^{\circ}{ }^{\circ}$ da Resolução CFC n. $\left.{ }^{\circ} 1.055 / 2005\right)$. No processo de audiência, o Comitê de Pronunciamentos Contábeis (CPC) consultará outras entidades e/ou instituições, como: Secretaria da Receita Federal, agências reguladoras, associações ou institutos profissionais, associações ou federações representativas da indústria, do comércio, da agricultura, do setor financeiro, da área de serviços, de investidores, instituições de ensino e/ou de pesquisa de Contabilidade e outras que tenham interesse direto nas questões definidas nos objetivos do Comitê de Pronunciamentos Contábeis (CPC), devendo, para cada uma delas, haver uma correspondência direta ou individualizada ( $§$ único do art. $6 .^{\circ}$ da Resolução CFC n. ${ }^{\circ}$ 1.055/2005).

Orientações e interpretações também poderão ser submetidas à audiência pública, porém, nesse caso, há uma mera faculdade e não uma obrigação, pois a legislação não assentou tal necessidade, como fez expressamente com os pronunciamentos técnicos.

A criação do $\mathrm{CPC}$ representou um avanço em termos de regulação normativa na área contábil. Isso porque, antes disso, cada um dos agentes reguladores que detinham poder normativo (CMN, CNSP e CVM) emitiam regulamentações contábeis de forma autônoma, o que gerava uma confusa colcha de retalho normativa, muitas vezes com regras contraditórias. Não havia uma interação entre os agentes reguladores que, via de regra, se preocupavam mais com questões peculiares do seu respectivo setor, sem que houvesse ações efetivas no sentido de promover uma sistematização coerente dos preceitos normativos na área contábil.

Outrossim, é importante destacar que, originalmente, o CFC não recebeu delegação de poder normativo para editar normas contábeis. Essa situação foi alterada apenas com a edição da lei n. ${ }^{0}$ 12.249/2010, que acrescentou a alínea " $\mathrm{f}$ " ao art. $6 .^{\circ}$ da decreto-lei n. ${ }^{\circ}$ 9.295/1946, atribuindo ao CFC competência para regular 
acerca dos princípios contábeis, do exame de suficiência, do cadastro de qualificação técnica e dos programas de educação continuada; e, principalmente, para editar Normas Brasileiras de Contabilidade de natureza técnica e profissional. Entretanto, mesmo antes do advento da lei n. ${ }^{\circ}$ 12.249/2010, o CFC já vinha exercendo um papel orientador, editando, com certa frequência, normas técnicas. Ocorre que, até então, só era possível reconhecer um papel orientador, pois, juridicamente, o poder normativo do CFC passou a existir apenas com o advento da lei $\mathrm{n}^{\circ}$ $12.249 / 2010$.

Nesse contexto, a criação do CPC viabilizou a existência de um fórum de discussão capaz de propor um marco normativo contábil mais homogêneo, permitindo, assim, a convergência às normas internacionais de contabilidade.

Por fim, é necessário fazer aqui uma consideração importantíssima e que, não raras vezes, passa despercebida por muitos daqueles que lidam com a legislação contábil. Os pronunciamentos técnicos, as orientações e interpretações oriundos do CPC não são normas jurídicas com eficácia vinculante em nosso ordenamento jurídico. Isso porque o CPC é um órgão de natureza privada que não dispõe de poder normativo, pois, no sistema jurídico brasileiro, apenas pessoas jurídicas de direito público podem ser contempladas com poder normativo, mediante uma delegação legislativa. Assim, para que os pronunciamentos técnicos, as interpretações e as orientações emitidas pelo CPC possam ter eficácia normativa, eles precisam ser internalizados ao ordenamento jurídico brasileiro mediante preceito normativo próprio dos órgãos e entidades contemplados com competência normativa em matéria contábil, sendo eles o CMN, o CNSP, a CVM e o CFC.

Sem a delegação legal, a edição de regras contábeis por órgãos ou entidades não passa de recomendações, não dispondo do atributo da imperatividade, que é característica marcante das normas jurídicas. Trata-se de uma decorrência do princípio da legalidade, previsto expressamente no art. 5. ${ }^{\circ}$, II, da CRFB/88, segundo o qual "ninguém será obrigado a fazer ou deixar de fazer alguma coisa senão em virtude de lei”; é uma máxima que representa um dos pilares do nosso sistema jurídico. De acordo com a postura assumida anteriormente, ao se comentar sobre o poder regulamentar no Brasil, apenas a lei pode delegar poder normativo em matéria contábil e, mesmo assim, dentro dos limites da delegação, não se admitindo poder normativo infralegal que contrarie lei em sentido formal

Apenas após essa providência é que os pronunciamentos, interpretações e orientações emitidos pelo CPC passam a ser considerados normas infralegais a gozar do atributo imperatividade. Antes disso são meras recomendações sem natureza vinculante.

Essa explanação é relevante porque evidencia que as normas internacionais de contabilidade emitidas pelo IASB não produzem efeitos imediatos no Brasil. O caráter impositivo apenas se fará presente depois de exaurido o complexo processo de internalização normativa requerido por nosso ordenamento jurídico; processo esse que requer a participação ativa do CPC, como forma de garantir um fórum mais amplo de discussão, mas que só se completa mediante a atuação efetiva dos órgãos e entidades dotados de competência normativa nas suas áreas específicas de atuação.

Importa destacar que o modelo de normatização contábil adotado no Brasil é similar ao implementado nos EUA. Nesse país, a Securities and Exchange Commission (SEC) - que é uma espécie de agência regulatória estatal - tem o poder de regular e fiscalizar o mercado de capitais, incluindo a definição de pronunciamentos contábeis aplicáveis. Ocorre que, desde sua gênese, no pós-Crash (década de 30), a SEC tem delegado a discussão técnica e emissão de pronunciamentos.

Atualmente, o papel de discussão tem sido liderado pelo Financial Accounting Standards Board (FASB), criado em 1973. Trata-se de uma entidade privada composta por membros com reconhecida capacidade técnica e que tem a missão de aperfeiçoar padrões de contabilidade financeira e divulgação para orientação e educação do público, incluindo produtores de informação, auditores e usuários de informações financeiras (HENDRISSEN e BREDA; 2012).

As normas emitidas pelo FASB são reconhecidas pela SEC (Securities and Exchange Comission) como tendo autoridade substantiva, e, portanto, são de observância obrigatória. Porém, o SEC reserva-se o direito de estabelecer reservas, determinando, em casos específicos, procedimentos que julgar apropriado para a elaboração e digulvação de informações contábeis. Outrossim, as empresas que não estão sujeitas ao SEC, também seguem as normas expedidas pelo FASB, via de regra, por imposição de regulamentação estadual da profissão contábil (HENDRISSEN; BREDA; 2012).

Com efeito, verifica-se que, no que toca á origem, o modo de elaboração das normas contábeis no Brasil e nos EUA são similares, uma vez que decorrem da manifestação de uma entidade privada composta por profissionais gabaritados. Contudo, é importante destacar uma diferença fundamental. Nos EUA, as normas produzidas pelo FASB têm aplicação imediata e só não serão observadas quanto expressamente afastadas por manifestação do 
SEC. Já no Brasil a situação é diferente, pois os pronunciamentos, as orientações e as interpretações emitidos pelo CPC não são normas jurídicas com caráter vinculante antes de ser internalizados no sistema jurídico por meio de ato normativo próprio das enteridades reguladoras dotadas de poder normativo.

\section{CONSIDERAÇÕES FINAIS}

A dinâmica negocial impôs a necessidade de se estabelecer uma padronização, mediante a definição de princípios e regras gerais norteadores dos registros contábeis, de modo a permitir que os dados financeiros pudessem ser interpretados pelos seus usuários. Dessa necessidade de padronização é que decorre a caminhada rumo à normatização contábil. $\mathrm{O}$ envolvimento dos diversos atores econômicos trouxe à tona a necessidade de fixação de normas gerais capazes de orientar os registros contábeis.

Ocorre que a normatização contábil apresenta caraterísticas próprias que se distanciam muito das formas tradicionais de estabelecimento de normas jurídicas, pautadas no princípio da legalidade. Destarte, tornou-se necessária uma releitura do modelo tradicional de criação do direito positivo, abrindo-se espaço para um campo maior de regulação infralegal, via de regra oriunda de órgãos e entidades administrativas dotados de conhecimentos técnicos em campos específicos de atuação.

Sob essa ótica, há que se proceder a uma flexibilização da concepção tradicional do princípio da legalidade, para que não seja um fim em si mesmo, sendo interpretado em consonância com o princípio da eficiência, de modo a reconhecer um largo campo de competência normativa infralegal, necessário para acompanhar a dinâmica evolução social no que toca à evidenciação, à mensuração e aos registros das operações contábeis.

Logo, os pronunciamentos técnicos, as interpretações e as orientações emitidas pelo CPC, após serem internalizados pelos órgãos e entidades da administração pública dotados de poder normativo, podem, sim, inovar no ordenamento jurídico, estabelecendo normas de natureza técnicas necessárias à regulação contábil, desde que o façam em conformidade com as leis que regem a matéria sob uma perspectiva finalística.

\section{REFERÊNCIAS}

FILHO, Edmar Oliveira Andrade. Imposto de Renda da Empresas. 10. ed. São Paulo: Atlas, 2013.

ÁVILA, Humberto. Teoria dos Princípios, da definição à aplicação dos princípios jurídicos. 10. ${ }^{\mathrm{a}}$ ed. São Paulo: Malheiros, 2009.

BOBBIO. Norberto. Teoria do Ordenamento Jurídico. 10. ${ }^{\mathrm{a}}$ ed. Tradução de Maria Celeste Cordeiro Leite dos Santos. Brasília: Editora Universidade de Brasília, 1999.

CARRAZA, Roque Antônio. Curso de Direito Constitucional Tributário. 20. a ed. São Paulo: Malheiros, 2004.

CARVALHO, Paulo de Barros. Curso de Direito Tributário. 17. a ed. São Paulo: Saraiva, 2005.

CARVALHOSA, Modesto. Comentários à lei de sociedades anônimas: lei n. ${ }^{\circ}$ 6.404, de 15 de dezembro de 1976. 2. ${ }^{\mathrm{a}}$ ed. 6. ${ }^{\circ}$ Volume. São Paulo: Saraiva, 1977.

DINIZ, Maria Helena. Lei de introdução ao Código Civil Brasileiro Interpretada. 16 ed. São Paulo: Saraiva, 2011.

FERNANDES, Edison Carlos. Direito Contábil: fundamentos, conceito, fontes e relação com outros ramos jurídicos. São Paulo: Dialética, 2013.

FILHO, José dos Santos Carvalho. Agências Reguladoras e Poder Normativo. ARAGÃO, Alexandre Santos de (Coord.). O Poder Normativo das Agências Reguladoras. 2. ${ }^{a}$ ed. 2011.

JUNIOR, Tercio Sampaio Ferraz. O poder normativo das Agências Reguladoras à luz do Princípio da Eficiência. In: ARAGÃO, Alexandre Santos de (Cood.) O Poder Normativo da Agências Reguladoras. 2. ${ }^{\text {ed. }}$ Rio de Janeiro: Forense, 2011.

KELSEN, Hans. Teoria Pura do Direito. Tradução de João Baptista Machado. 6. ${ }^{a}$ ed. São Paulo: Marins Forense, 
1998.

GRAU, Eros Roberto. O direito posto e o direito pressuposto. $3 .^{\circ}$ ed. São Paulo: Malheiros, 2000.

HENDRIKSEN, Eldon S.; BREDA, Michel F. Van. Teoria da Contabilidade. Tradução de Antônio Zoratto Sanvicente. $1^{\text {a }}$ ed. São Paulo: Atras, 2012.

IUDÍCIBUS, Sérgio de; FILHO, Álvaro Augusto Ricardino. A Primeira Lei das Sociedades Anônimas no Brasil Lei n. ${ }^{\circ} 1.083$ - 22 de Agosto de 1860. Revista Contabilidade Finanças - USP, São Paulo, n. 29, p. 7 - 25 , maio/ago. 2002.

SÁ, Antônio Lopes de. Teoria da Contabilidade. 3. ${ }^{\circ}$ ed. São Paulo: Atlas, 2002.

STRECK, Lenio luiz. Hermenêutica e(m) crise: Uma exploração hermenêutica da construção do direito. $5 .^{\circ}$ ed. Porto Alegre: Livraria do Advogado Editora, 2004.

MAMEDE, Gladston. Direito empresarial brasileiro: empresa e atuação empresarial. Vol. $1,5 .^{\circ}$ ed. São Paulo: Atlas, 2011.

MARTINS, Eliseu et. al. Manual de Contabilidade Societária. 2. ${ }^{a}$ ed. São Paulo: Atlas, 2013.

MELlO, Celso Antônio Bandeira de. Curso de Direito Administrativo. 28. a ed. São Paulo: Malheiros, 2011.

MOREIRA, Egon Bockmann. Os Limites à Competência Normativa das Agências Reguladoras. In: ARAGÃO, Alexandre Santos de (Coord.) O Poder Normativo das Agências Reguladoras. 2. ${ }^{a}$ ed. Rio de Janeiro: Forense, 2011. 